AGRICULTURE AND BIOLOGY JOURNAL OF NORTH AMERICA

ISSN Print: 2151-7517, ISSN Online: 2151-7525, doi:10.5251/abjna.2011.2.3.415.420

(C) 2011, ScienceHu $\beta$, http://www.scihub.org/ABJNA

\title{
Evaluation of Engeo K 247 SC for routine protection of cocoa farms against the brown Cocoa Mirid - Sahlbergella singularis in Nigeria
}

\author{
*Asogwa, E.U.; F.A. Okelana; T.C.N. Ndubuaku; I.U. Mokwunye and J.C. Anikwe \\ Crop Protection Division, Cocoa Research Institute of Nigeria, Ibadan \\ *Corresponding Author: ucheasogwa1@yahoo.com
}

\begin{abstract}
Laboratory and field screening of Engeo $\mathrm{K} 247 \mathrm{SC}$ was carried out at three concentrations, $0.0625 \%, 0.125 \%$ and $0.25 \%$ active ingredient between 2005 and 2007 to determine its suitability for use on cocoa farms in Nigeria. The mortality rates of mirids on exposure to the various concentrations of Engeo K 247 SC increased with period of exposure of the mirids in the laboratory. Engeo K 247 SC and the Standard Miricide were similar at $0.125 \%$ concentration as both gave a $100 \%$ kill of mirids at the $70^{\text {th }}$ minute. No mortalities were recorded in the control petridishes throughout the exposure period. The insecticide did not produce any adverse side effects on cocoa seedlings and mature plants sprayed with the various concentrations over the years. The mirid mortality recorded after the first year's initial and residual treatment applications at Ibadan, Owena and Ikom at the lowest concentration of $0.0625 \%$ was 78 to $100 \%$, while 70 to $100 \%$ was recorded in the second year. They all compared effectively with the mortalities recorded at $0.125 \%, 0.25 \%$ and the Standard Miricide concentrations (80.4 to $100 \%)$. Spraying of mature and fruiting cocoa farms at application rate of $0.125 \%$ was found adequate taking into consideration the impact of the product on the environment and for economic reasons. However, final recommendation is yet to be given for the use of the insecticide on cocoa in Nigeria.
\end{abstract}

Keywords: Brown cocoa mirids, concentration, exposure, spraying, mortality

\section{INTRODUCTION}

The cocoa mirid Sahlbergella singularis still constitutes the major contributory factor to over $30 \%$ yield loss in unkept cocoa plots in Nigeria. The feeding activities of the insect result in direct injury to the plant tissue and indirectly predispose such tissue to secondary infection by rot organisms. Chemical control still remains a very important component among the strategies for effective control of mirids and other economically important insect pests of cocoa in Nigeria. There is therefore continuous need to screen insecticides from various chemical groups (Organophosphates, Carbamates, Pyrethroids etc).

The Cocoa Research Institute of Nigeria (CRIN) has the national mandate to evaluate and recommend novel cocoa pesticides from various groups that fall within the European Union (EU) standards so that replacement could be made easily in a situation where they become unavailable in the local market or to combat resistance problems that may arise as a result of over-dependence on a particular class of insecticides. Such insecticides usually undergo rigorous testing to determine and recommend the correct dose necessary to produce toxic reactions to the targeted pest without any adverse effects on the environment and non-target organisms.

Nigeria is currently the $4^{\text {th }}$ world producer of cocoa with an estimated production figure of 219,000 metric tons in 2008/09 (FAO, 2007; ICCO, 2008). Mirid damage is one of the three most important scourges affecting cocoa production in West African cocoa growing countries. The other two scourges are the cocoa swollen shoot virus disease transmitted by mealybugs, and the black pod disease caused by Phytophthora palmivora and the more virulent and recently introduced $P$. megakarya. The feeding activities of mirids are characterized by dark markings (lesions) on both pods and shoots, which result from the collapse of plant tissue caused by the toxic saliva of mirids. Secondary damages (canker and dieback) occur when the feeding lesions are invaded by parasitic fungi notably Calonectria rigidiuscula Berk. \& Br. (Sacc.) and Fusarium spp (Entwistle, 1964; 1972).

Engeo $\mathrm{K} 247 \mathrm{SC}$ is an insecticide formulation containing active ingredients of Thiamethoxam 14.1\% $\mathrm{w} / \mathrm{v}$ and Lamda-cyhalothrin $10.1 \% \mathrm{w} / \mathrm{v}$ per litre. The 
Agric. Biol. J. N. Am., 2011, 2(3): 415-420

evaluation of the efficacy of the insecticide for routine protection of cocoa farms against the insect pest was carried out at the peak of mirid season from 2005 to 2007 with laboratory and small-scale field tests in three Nigerian cocoa agroecologies (Ibadan, Owena and Ikom). Syngenta Nigeria Limited sponsored and financed main aspects of the project.

The detailed results of the various aspects of the evaluation and other technical information on the insecticide, which are pertinent to the conclusion and recommendation made here, are given in various sections of this report.

TECHNICAL INFORMATION ON ENGEO K 247 SC

Manufacturer: Syngenta Crop Protection AG

Trade Name: Engeo K 247 SC

Code number: CGA293343/ ASF 364

Design Code: A13623B

\section{Chemical Abstracts Service \\ (CAS)-Registry number:} 153719-23-4/ 91465-08-06

Active Ingredient (a.i.):

Thiamethoxam $14.1 \%$ w/v + LambdaCyhalothrin $10.6 \%$ w/v.

Insecticide Group: Neonicotinoid / Pyrethroid pesticide

Insecticide formulation/Form: Suspension Concentrate

Physical state: Liquid

Colour: Light beige

Density: $\quad 1.118 \mathrm{~g} / \mathrm{ml}\left(20^{\circ} \mathrm{C}\right)$

PH: $\quad 6-7(1 \%)$

Relative Self-Ignition temperature: $\quad 620{ }^{\circ} \mathrm{C}$ Flash - Point: $\quad>102{ }^{\circ} \mathrm{C}(763 \mathrm{mmHg})$

Oxidizing properties: Not oxidizing

Explosive properties: Not explosive
Corrosiveness:

$0.04 \mathrm{~g} / \mathrm{m} 2 * \mathrm{~h}$ (sheet steel)

$0.07 \mathrm{~g} / \mathrm{m} 2^{*}$ (galvanized sheet metal)

Shock sensitivity:Not shock sensitive

Thermal sensitivity: Thermally not sensitive

Chemical stability:Stable under standard conditions

Product specific safety date: Highly degradable

WHO hazard rating: Class III

Acute oral toxicity: $\quad$ LD50 Rat, $>310.2 \mathrm{mg} / \mathrm{kg}$

Acute dermal toxicity: LD50 Rat, $>2,000 \mathrm{mg} / \mathrm{kg}$

Acute inhalation toxicity:LC50 Rat, $>2.15 \mathrm{mg} / \mathrm{l}, 4 \mathrm{~h}$

METHODOLOGY

Laboratory tests: The efficacy of Engeo K 247 SC under laboratory conditions of temperature and relative humidity $27 \pm 3^{\circ} \mathrm{C}$ and $60 \pm 10 \%$, respectively were tested at three concentrations $(0.0625 \%$, $0.125 \%$ and $0.25 \%)$. A mixture of nymphs $\left(3^{\text {rd }}-5^{\text {th }}\right.$ instars) and adults of $S$. singularis collected from cocoa plots at CRIN Headquarters, Ibadan, were exposed to filter papers impregnated with various concentrations of the insecticide inside micro-cages of transparent plastic petri-dishes with perforated lids. Ten mirids were placed in each Petri-dish. A standard miricide was used for comparison while distilled water was used as control. The experimental design was a Completely Randomized Design with 5 replications per treatment. Mortality of the mirids was recorded at ten minutes intervals for 2 hours, which was the maximum time period it took to achieve $100 \%$ mortality in over $60 \%$ of the cages.

Phytotoxicity tests: For three consecutive years (2005 - 2007), one thousand $(1,000)$ cocoa seedlings in CRIN nursery were sprayed with Engeo K 247 SC at various concentrations. Three applications were made each year at 35 days intervals. The test was extended to same number of mature cocoa trees in the plots ( $1 \mathrm{ha})$ within the same time period in the three cocoa agroecological zones. The treated plants were routinely observed for possible adverse side effects of the pesticides such as wilting, scorching, necrosis as well as outbreak of any unusual insect pests and diseases in the nursery and in the treated cocoa plots. 
Field tests: The efficacy of Engeo K 247 SC was tested at three concentrations, $0.0625 \%, 0.125 \%$ and $0.25 \%$ during the peak of mirid season from 2005 to 2007. The treatment plots contained five trees each separated by three rows of trees. The experimental design was a randomized complete block design (RCBD) with three replications. A standard miricide was used for comparison, while the control plot was not sprayed. The trial was conducted at three locations; Ibadan (Oyo State), Owena (Ondo State) and Ikom (Cross-River State). The spray mixture was applied with a lever-operated knapsack-spraying pump (CP15). Field applications were carried out between 7am and 9a.m. The two applications were made during the peak mirid season, each at 35 days interval. Pre and post-spray application records were taken. Percentage mortality was computed to determine the relative toxicity of the three concentrations applied. These were compared with percentage mortality in unsprayed sub-plots.

\section{RESULTS}

Laboratory tests: Figure 1 shows that Engeo K 247 SC was lethal to cocoa mirids at all the three concentrations tested in the laboratory bioassay. Mortality increased with period of exposure. The mortality rates of Engeo K 247 SC at $0.125 \%$ and $0.25 \%$ a.i. were slightly faster than in the standard miricide up to the $70^{\text {th }}$ minute. No mortalities were recorded in control petridishes throughout the exposure period. Engeo K $247 \mathrm{SC}$ and the standard miricide were similar at $0.125 \%$ concentration as both gave a $100 \%$ kill of mirids at the $70^{\text {th }}$ minute.

Phytotoxicity tests: The insecticide (Engeo K 247 SC) did not produce any general adverse side effects such as wilting, scorching, necrosis as well as outbreak of any unusual insect pests on cocoa seedlings and mature plants sprayed with the various concentrations over the years. A zero percent toxicity was recorded on both the cocoa seedlings and mature trees in the plots after treatment (Table 1).

Table 1:Summary result of phytotoxicity of Engeo K 247 SC to cocoa seedlings in the nursery and mature trees in the plots

Location: $\quad$ CRIN Headquarters, Ibadan

\begin{tabular}{|c|c|c|c|c|c|c|c|}
\hline \multicolumn{3}{|c|}{$1^{\text {st }}$ Yr. Application } & \multicolumn{3}{|c|}{$2^{\text {nd }}$ Yr. Application } & \multicolumn{2}{|c|}{$3^{\text {rd }}$ Yr. Application } \\
\hline Concentration & $\begin{array}{l}\text { No of } \\
\text { cocoa }\end{array}$ & $\begin{array}{l}\text { Infested } \\
\text { cocoa }\end{array}$ & \%Toxicity & $\begin{array}{l}\text { Infested } \\
\text { cocoa }\end{array}$ & \%Toxicity & $\begin{array}{l}\text { Infested } \\
\text { cocoa }\end{array}$ & \%Toxicity \\
\hline \multicolumn{8}{|l|}{ Cocoa seedlings } \\
\hline $0.0625 \%$ & 1000 & 0 & $0 \%$ & 0 & $0 \%$ & 0 & $0 \%$ \\
\hline $0.125 \%$ & 1000 & 0 & $0 \%$ & 0 & $0 \%$ & 0 & $0 \%$ \\
\hline $0.25 \%$ & 1000 & 0 & $0 \%$ & 0 & $0 \%$ & 0 & $0 \%$ \\
\hline Std. & 1000 & 0 & $0 \%$ & 0 & $0 \%$ & 0 & $0 \%$ \\
\hline Control & 1000 & 0 & $0 \%$ & 0 & $0 \%$ & 0 & $0 \%$ \\
\hline \multicolumn{8}{|c|}{ Mature cocoa trees } \\
\hline $0.0625 \%$ & 1000 & 0 & $0 \%$ & 0 & $0 \%$ & 0 & $0 \%$ \\
\hline $0.125 \%$ & 1000 & 0 & $0 \%$ & 0 & $0 \%$ & 0 & $0 \%$ \\
\hline $0.25 \%$ & 1000 & 0 & $0 \%$ & 0 & $0 \%$ & 0 & $0 \%$ \\
\hline Std. & 1000 & 0 & $0 \%$ & 0 & $0 \%$ & 0 & $0 \%$ \\
\hline Control & 1000 & 0 & $0 \%$ & 0 & $0 \%$ & 0 & $0 \%$ \\
\hline
\end{tabular}



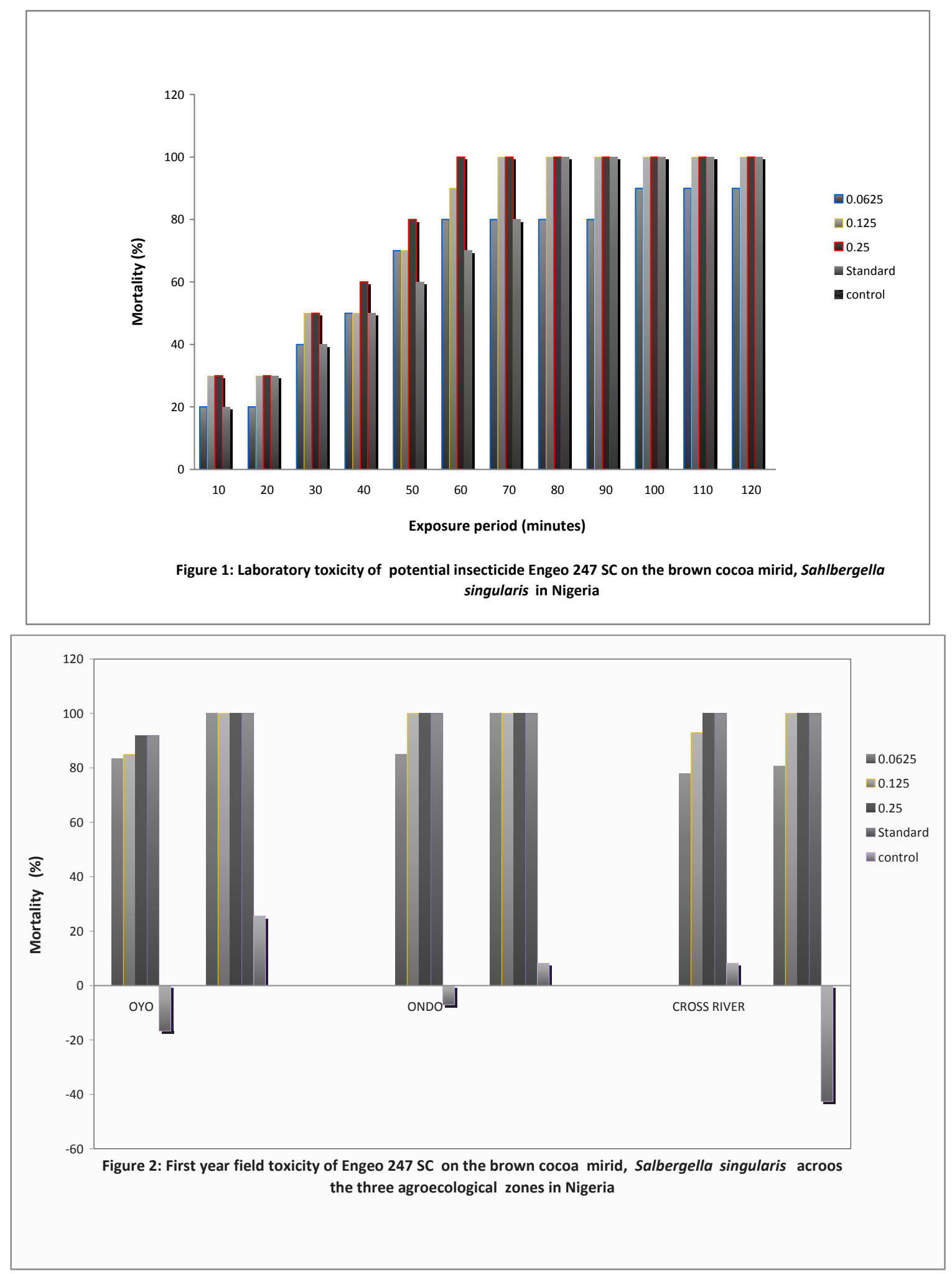

First year field tests: Figure 2 shows the relative toxicity of Engeo K 247 SC at various concentrations
$(0.0625 \%, \quad 0.125 \%$ and $0.25 \%)$ to a mixture of nymphs and adult mirids. The mortalities of mirids 
recorded after the initial and residual treatment applications at Ibadan, Owena and Ikom at the lowest concentration of $0.0625 \%$ was between $78 \%$ and $100 \%$, which compared effectively with the $0.125 \%$, $0.25 \%$ and standard miricide concentrations $(85.0 \%$ $100 \%)$.

Second year field tests: Figure 3 shows the relative toxicity of Engeo K 247 SC at various concentrations
$(0.0625 \%, 0.125 \%$ and $0.25 \%)$ to a mixture of nymphs and adult mirids. The mortalities of mirids recorded after the initial and residual treatment applications at Ibadan, Owena and Ikom at the lowest concentration $0.0625 \%$ ranged between $70 \%$ and $100 \%$, which compared effectively with the $0.125 \%$, $0.25 \%$ and standard miricide concentrations (80.4\% $100 \%)$.

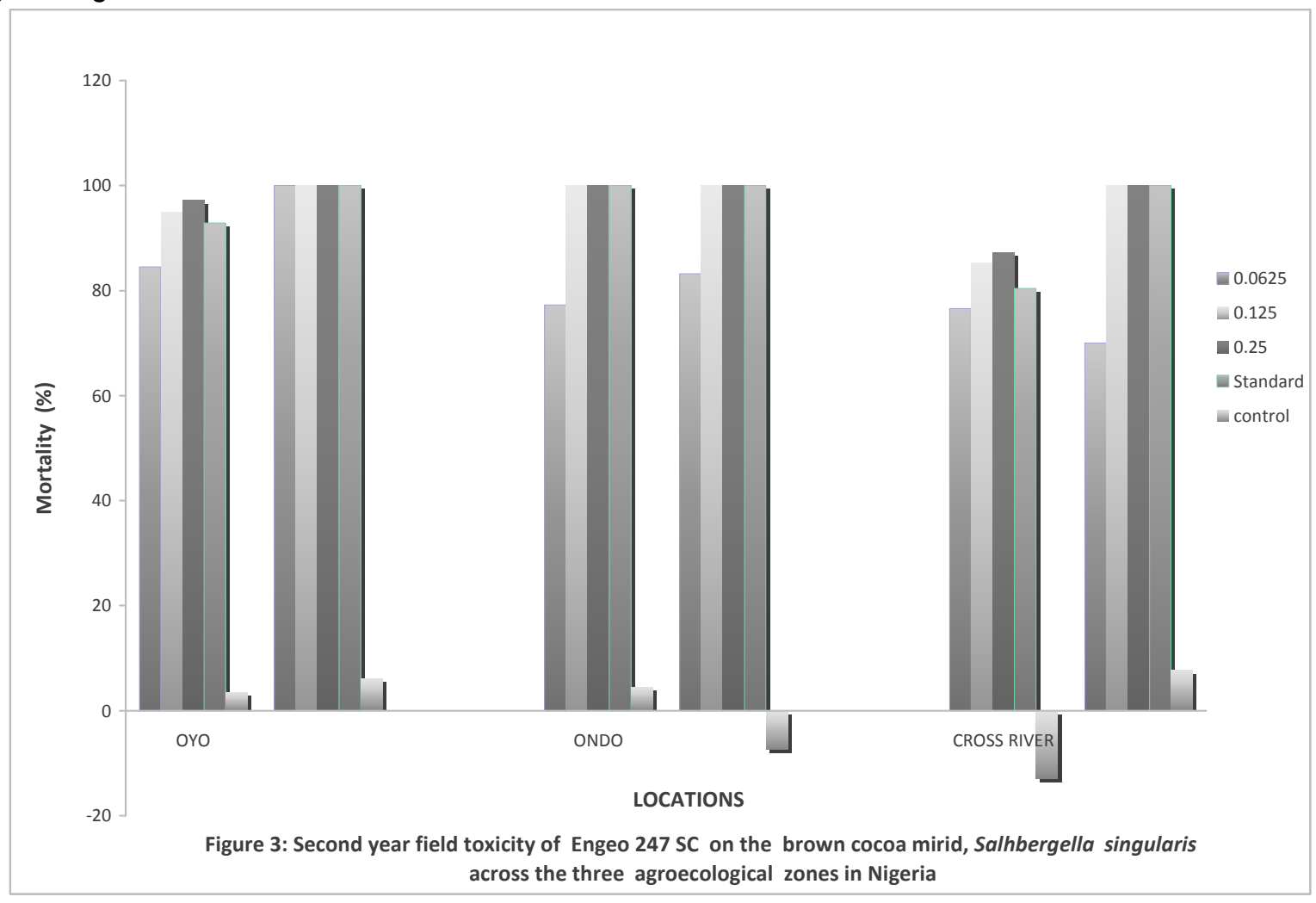

\section{DISCUSSION}

Insecticides undergo rigorous testing to determine the dose necessary to produce a toxic reaction. "LD 50 " is a term often used to rank insecticides by their toxic levels. The lower the LD 50, the more toxic the insecticide. For example, Nicotine, considered a natural insecticide, is extremely toxic with an oral LD 50 of 55 (Hillock and Bolin, 2004). With acute oral and dermal toxicity of LD50 Rat, $>5,000 \mathrm{mg} / \mathrm{kg}$ and acute inhalation toxicity of LC50 Rat, $>5,290 \mathrm{mg} / \mathrm{m}^{3}$, $4 \mathrm{~h}$ on rats (NRA, 2001), Engeo K 247 SC was considered safe for use. The screening process of Engeo K 247 SC at CRIN depended largely on the field populations of mirids, which accounted for the number of years taken to achieve the completion of the process.
The negative values recorded for the non-treated controls indicate infestation resulting from either further breeding of resident mirid colonies or mirid influx from neighbouring unsprayed plantations.

A multilocational approach was adopted in carrying out the screening of new insecticides so as to ascertain the suitability of the insecticides at the various Nigerian cocoa agroecologies. Ibadan (Oyo State) represents a marginal area for cocoa production with a typical rain forest, mild dry period and humid area with high black pod history. Owena (Ondo State) is a forest, humid area with high black pod history too, while Ikom (Cross-River State) is a humid forest area with early crop season and has very high black pod history. 


\section{CONCLUSION}

ENGEO K 247 SC, when routinely sprayed to protect cocoa farms against the cocoa mirid in the field, was found to be efficacious as other standard insecticides approved for routine protection of cocoa in Nigeria. Consequently, the insecticide may prove to be a potential pesticide for use on cocoa farms in Nigeria. However, the recommendations of the insecticide use on cocoa in Nigeria is still pending as a result of the decision of the company to suspend further action on the final protocol, which is the residue and taint analysis on the cocoa beans from treated plots.

\section{ACKNOWLEDGEMENT}

The authors wish to thank the Management of Cocoa Research Institute of Nigeria and Syngenta Nigeria Limited for their support.

\section{REFERENCES}

Entwistle, P.F. (1964) The distribution of mirid species and resistant mirids in Nigeria. Proc. Conf. Mirids and other pests of cocoa, 1964. Ibadan, Nigeria. Pp. 9-17.
Entwistle P.F. (1972). Pests of Cocoa. Longman Group Ltd. London. 778 pp.

FAO (2007). World cocoa beans production (Thousand metric tons).

online@www.unep.org/pdf.PressRelease/Ghana Africa Atlas.pdf

Hillock, D. and P. Bolin (2004). Botanical pest controls. Oklahoma Cooperatives Extension fact Sheets. HLA6433-4. Available online@http://osustate.edu

ICCO (2008) Forecasts of National and Regional cocoa production through to 2012/13.

online@http://www.icco.org/documents/documents3.as px-23k

National Registration Authority for Agriculture and Veterinary Chemical (NRA) (2001). Public release summary on evaluation of new active Thiamethoxam. Kingstonnet 2604 ISSN 1443 - 1335. 34pp. 